Bangladesh J. Zool. 39(2): 195-204, 2011

\title{
BASELINE INVESTIGATION ON RABIES IN RANGPUR AND CHITTAGONG DIVISIONS, BANGLADESH
}

\author{
Md. Abdul Gofur, Hamida Khanum, Milka Patracia Podder and Rubayet Elahi \\ Department of Zoology, University of Dhaka, Dhaka-1000, Bangladesh
}

\begin{abstract}
Baseline investigation on rabies in Chittagong and Rangpur divisions was evaluated for the first time in Bangladesh from June 2010 to January 2011. A total of 600 respondents was interviewed including common people, school teachers, peoples' representatives, political leaders, doctors and nurses and Medical technicians from selected households. Approximately $89 \%$ of the respondents heard the name of rabies. Regionally $86 \%$ of the respondents in Rangpur division and 91\% in Chittagong division possessed information fully or partly about rabies. The higher rate $(91 \%)$ of respondents heard about rabies in Chittagong division and sources of respondent's knowledge about rabies comprised mostly radio, TV, health worker and other sources. Approximately $100 \%$ of the respondents of different categories would seek treatment from the hospital. Majority knew about the fate of rabies that is ultimate death and believed that rabies could be prevented by vaccination program. Regarding the control of stray and poorly supervised dogs, the majority of the participants suggested for the elimination of the dogs.

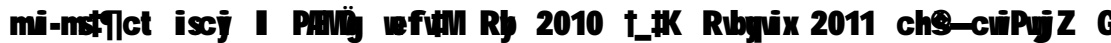

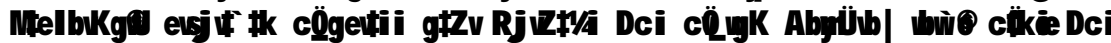

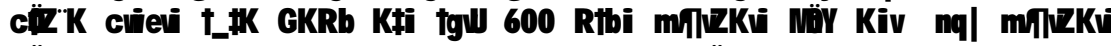

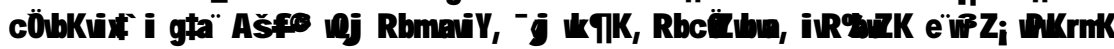

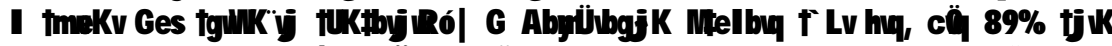

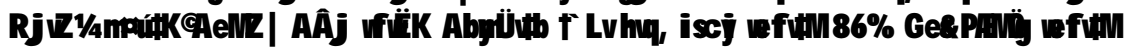

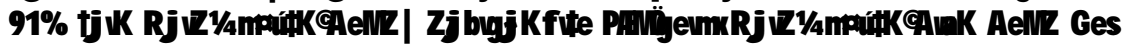

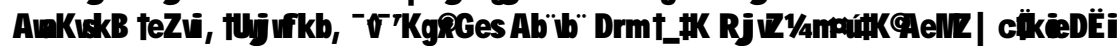

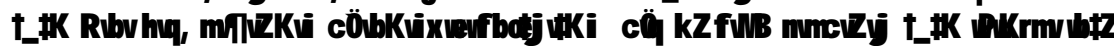

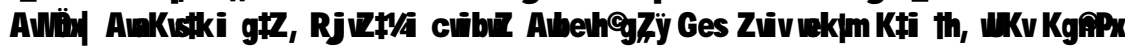

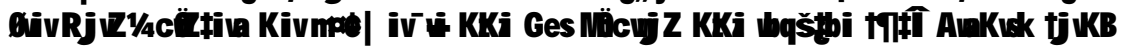
$K \forall \dot{Z}$ wbałbi $c \neq \emptyset \quad g Z$ ẁ $\neq a \neq Q b \mid$
\end{abstract}

Key words: Baseline, rabies, division, demography, prevalence, education,

\section{INTRODUCTION}

Approximately 40,000 people die each year worldwide from rabies; most of the deaths occur in China, Bangladesh and Pakistan, where rabies is endemic and healthcare is poor (RRPB 1999). More than 99\% human deaths due to rabies occur in the developing world, and the disease has not been brought under control throughout most of the affected countries (WHO 2004). A national program for the control and eradication of human and animal rabies in Sri Lanka has been adopted since the mid-1970s; the program made provisions for the immunization of dogs to achieve $75-80 \%$ vaccination coverage, elimination of 
stray dogs, post exposure prophylaxis (PEP) for suspected animal-bite victims, and other related issues including the periodic evaluation of the rabies control program (Matter et al. 2000).

Rabies is a preventable viral disease of mammals, most often transmitted through the bite of rabid (mad) animals (dogs and cats). The vast majority of rabies cases reported to the Centers for Disease Control and Prevention (CDC) each year occur in wild animals like raccoons, skunks, bats, and foxes (CDC 2011). An estimated six million people undergo Post-Exposure Treatment (PET) of rabies annually worldwide (Wilde 1996). In the United States, approximately 40,000 people receive PET annually while there has been an average of three fatal cases of human rabies per year since 1980 (Messenger et al. 2002). Rabies is also emerging as an important disease in North America as several cases of human rabies have been reported due to exposure to bats (Krebs et al. 2004).

Rabies is a major public health problem, distributed uniformly in all parts of the world. Despite the discovery of Anti-Rabies Vaccine (ARV) by Louis Pasteur in the year 1851, the World Health Organization estimates that between 30,000 and 70,000 people die worldwide of rabies each year (Knobel et al. 2005). Most of these deaths occur in developing countries because of inadequate control of rabies in domesticated animals, and about 30,000 death results in India alone (Sehgal et al. 1997, Singh et al. 2001).

In Asia, eight countries are free of rabies, namely, Bahrain, Hong Kong, Japan, Malaysia, Qatar, Singapore, Taiwan and the United Arab Emirates (Beran and Steele 1994). The main route of rabies virus transmission in Asia is through rabid dog bites which are responsible for $96-98 \%$ of deaths from rabies in humans-other animal species may also be infected (cats, cattle, monkeys and mongoose) and serologic evidence of infection in bats has also been documented in Cambodia (Reynes et al. 2004).

There is no accurate statistical data on rabies collected in Bangladesh. From the scattered hospital records it is assumed that about two thousand persons die of rabies per year. From the vaccine supplies records it is evident that about 60000 persons undergo post-exposure treatment after animal bites every year, of which $95 \%$ are dog bite cases. About $45 \%$ of the total number of persons undergoing post-exposure treatment is children of 3-5 years (RRPB 1999). Now a days, though many people are aware of the disease, they still neglect animal bites and remain unnoticed and untreated.

\section{OBJECTIVE}

The objective of the study was to determine the baseline of scientific and credible knowledge regarding human rabies and its relation with pet and stray 
animals, to know about the personal, social and religious beliefs regarding rabies, animal bite/scratches and the actions and measures taken by people to prevent or treat rabies particularly following an animal bite/scratch or developing full blown rabies in man and cattle.

\section{MATERIAL AND METHODS}

A cross sectional study was carried out from June 2010 to January 2011 in selected areas of Chittagong and Rangpur divisions by conducting face-to-face interviews using structured questionnaires among respondents of various categories including common people, school teacher, people representative, political leader, doctor and nurse, and Medical technician from selected households. The data were collected from Rangpur and Chittagong divisions which are 350 kilometers and 264 kilometers away from the capital Dhaka, respectively. The age limit of the respondents was 16-85 years and about 600 respondents were studied. The households were chosen randomly. One person from each household was interviewed. The following general characteristics of a target population were included in the survey: age, sex, status in the family, level of education, prevention practice, treatment practice, control practice etc. The sample were calculated using appropriate statistical formula. Statistical analysis have been performed to find out if there was any significant relationship among the variables in respect to age, sex, occupation, housing, media facility, level of education etc. The data were analyzed using SPSS version 16.0.

\section{RESULTS AND DISCUSSION}

In Rangpur division, the highest 21.7 percent of the respondents had monthly income Tk.12,000-18,000 and the lowest six percent had above Tk.30,000. Similarly, the highest 22.3 percent of the respondents had monthly income Tk.12,000-18,000 and the lowest 2.3 percent had above Tk.30,000 in Chittagong division.

The highest 70 and the lowest 0.7 percents of the respondents had tin shade and wooden houses, respectively in Chittagong division. Similarly, in Rangpur division, the highest 62.7 and the lowest $1.3 \%$ percents of the respondents had the same type of houses, respectively.

The highest 26.7 percent of the respondents had bachelor or fazil degree and the lowest 2.3 percent had postgraduate medical or engineering degree in Chittagong division. Similarly, in Rangpur division, the highest 23.7 percent of the respondents had bachelor or fazil degree and the lowest two percent had postgraduate medical or engineering degree. The percentage of the illiterate 
respondents was 4.3 and 8.3 in Chittagong and Rangpur divisions, respectively (Table 1).

In Rangpur division $86 \%$ and in Chittagong division, $91 \%$ of the respondents heard the name of rabies. Among the respondents the number of different categories of people aware of rabies were: 113 common people, 59 school teacher, nine peoples' representatives, 18 political leaders, 30 doctors and 29 nurses + MTs in Rangpur division and in Chittagong division, they were 133, 59, 9, 15, 30 and 30, respectively. In both divisions, most of the respondents were informed of rabies from radio, TV, family and other sources (Table 2). The higher rate $(91 \%)$ of respondents heard of rabies in Chittagong division might be due to the fact that there are higher level of education and family income in this division. In Sri Lanka as many as $94.5 \%$ of respondents had information about rabies and most of the information came from various sources, such as trimedia (radio, newspaper, television), school, neighbors and friends, and government campaigns (Matibag et al. 2007).

Table 1. The level of education among the respondents.

\begin{tabular}{lccc}
\hline \multirow{2}{*}{ Level of education } & \multicolumn{2}{c}{ Division } & \multirow{2}{*}{$\begin{array}{c}\text { Total } \\
\text { \% (Number) }\end{array}$} \\
\cline { 2 - 3 } & $\begin{array}{c}\text { Chittagong } \\
\% \text { (Number) }\end{array}$ & $\begin{array}{c}\text { Rangpur } \\
\% \text { (Number) }\end{array}$ & \\
\hline Illiterate & $4.3(13)$ & $8.3(25)$ & $6.3(38)$ \\
Primary or under five madrasha & $7.3(22)$ & $8.7(26)$ & $8.0(48)$ \\
Class eight/below dakhil madrasha & $9.7(29)$ & $9.3(28)$ & $9.5(57)$ \\
SSC or Dakhil & $18.0(54)$ & $18.0(54)$ & $18.0(108)$ \\
HSC or Alim & $18.7(56)$ & $17.4(52)$ & $18.0(108)$ \\
Bachelor or Fazil & $26.7(80)$ & $23.7(71)$ & $25.2(151)$ \\
Masters or Kamil & $5.0(15)$ & $4.3(13)$ & $4.7(28)$ \\
Graduate (MBBS) medical or engineering & $8.0(24)$ & $8.3(25)$ & $8.1(49)$ \\
Postgraduate medical or engineering & $2.3(7)$ & $2.0(6)$ & $2.2(13)$ \\
\hline Total & $100.0(300)$ & $100.0(300)$ & $100.0(600)$ \\
\hline
\end{tabular}

In Rangpur division $86 \%$ of the respondents would arrange treatment if any family member is bitten by dog and in Chittagong division, $91 \%$ of the respondents would arrange treatment for their affected family member. In Rangpur division, the number of categories of respondents who would take rabies treatment for their family members included 113 common people, 59 school teachers, nine peoples' representatives, 18 political leaders, 30 doctors and 30 nurses + MTs. Similarly, in Chittagong division the numbers were 133, 59, 6, 15, 30 and 30, respectively. Among the respondents in both divisions, all categories would arrange treatment from hospital doctors, if they are bitten by dogs (Table 3). In Sri Lanka 96\% of the people would seek treatment from a doctor or a hospital after being bitten by dog; this high level of awareness might 
be due to the availability of information from multiple sources including government campaigns and mass media in addition to the free medical services available in government hospitals (Matibag et al. 2007).

Table 2. Percentage of the respondents of different category regarding the knowledge on source of rabies.

\begin{tabular}{|c|c|c|c|c|}
\hline \multirow[b]{2}{*}{ Category } & \multirow[b]{2}{*}{ Source of information } & \multicolumn{2}{|c|}{ Division } & \multirow{2}{*}{$\begin{array}{c}\text { Total } \\
\%(\text { Number) }\end{array}$} \\
\hline & & $\begin{array}{c}\text { Rangpur } \\
\%(\text { Number) }\end{array}$ & $\begin{array}{l}\text { Chittagong } \\
\%(\text { Number) }\end{array}$ & \\
\hline \multirow{5}{*}{$\begin{array}{l}\text { Common } \\
\text { people }\end{array}$} & Radio, TV & $10.6(12)$ & $14.3(19)$ & $12.6(31)$ \\
\hline & Health Worker & $10.6(12)$ & $13.5(18)$ & $12.2(30)$ \\
\hline & Family Member & $22.1(25)$ & $25.6(34)$ & $24.0(59)$ \\
\hline & Other Source & $54.0(61)$ & $43.6(58)$ & $48.4(119)$ \\
\hline & Radio, TV and Health Worker & $2.7(3)$ & $3.0(4)$ & $2.8(7)$ \\
\hline Total & & $100.0(113)$ & $100.0(133)$ & $100.0(246)$ \\
\hline \multirow{4}{*}{$\begin{array}{l}\text { School } \\
\text { teacher }\end{array}$} & Radio, TV & $22.0(13)$ & $10.2(6)$ & $16.1(19)$ \\
\hline & Health Worker & $18.7(11)$ & $15.3(9)$ & $16.9(20)$ \\
\hline & Family Member & $28.8(17)$ & $27.1(16)$ & $28.0(33)$ \\
\hline & Other Source & $30.5(18)$ & $47.4(28)$ & $39.0(46)$ \\
\hline Total & & $100.0(59)$ & $100.0(59)$ & $100.0(118)$ \\
\hline \multirow{3}{*}{$\begin{array}{l}\text { People } \\
\text { representative }\end{array}$} & Radio, TV & $11.2(1)$ & $16.7(1)$ & $13.3(2)$ \\
\hline & Health Worker & $44.4(4)$ & $16.7(1)$ & $33.3(5)$ \\
\hline & Other Source & $44.4(4)$ & $66.6(4)$ & $53.4(8)$ \\
\hline Total & & $100.0(9)$ & $100.0(6)$ & $100.0(15)$ \\
\hline Political & Radio, TV & $38.9(7)$ & $6.7(1)$ & $24.2(8)$ \\
\hline \multirow[t]{3}{*}{ Leader } & Health Worker & $16.6(3)$ & $13.3(2)$ & $15.2(5)$ \\
\hline & Family Member & $5.6(1)$ & $20.0(3)$ & $12.1(4)$ \\
\hline & Other Source & $38.9(7)$ & $60.0(9)$ & $48.5(16)$ \\
\hline Total & & $100.0(18)$ & $100.0(15)$ & $100.0(33)$ \\
\hline \multirow[t]{4}{*}{ Doctor } & Radio, TV & $6.7(2)$ & $6.7(2)$ & $6.7(4)$ \\
\hline & Health Worker & $6.7(2)$ & $6.7(2)$ & $6.7(4)$ \\
\hline & Family Member & $23.3(7)$ & $23.3(7)$ & $23.3(14)$ \\
\hline & Other Source & $63.3(19)$ & $63.3(19)$ & $63.3(38)$ \\
\hline Total & & $100.0(30)$ & $100.0(30)$ & $100.0(60)$ \\
\hline \multirow[t]{4}{*}{ Nurse + MT } & Radio, TV & $13.8(4)$ & $16.7(5)$ & $15.3(9)$ \\
\hline & Health Worker & $44.8(13)$ & $60.0(18)$ & $52.5(31)$ \\
\hline & Family Member & $13.8(4)$ & $10.0(3)$ & $11.9(7)$ \\
\hline & Other Source & $27.6(8)$ & $13.3(4)$ & $20.3(12)$ \\
\hline Total & & $100.0(29)$ & $100.0(30)$ & 100.0 (59) \\
\hline
\end{tabular}

In Rangpur division, $85.3 \%$ of the respondents and in Chittagong division, $89.3 \%$ of the respondents knew the fate of rabies. In Rangpur division the number of categories of the respondents who knew the fate of rabies were: 111 common peoples, 59 school teachers, nine peoples' representatives, 18 political leaders, 30 doctors and 29 nurses + MTs in Rangpur division and in Chittagong division, the numbers were $129,59,6,14,30$ and 30 , respectively. In both divisions, the high level professionals among the respondents were quite sure 
about the fate of rabies (i.e. death). Most of the other categories also answered death (Table 4). In the rural areas near New Delhi, $84.0 \%$ of respondents were aware that dog bites might cause death (Agarwal and Reddaiah 2003). The long historical presence of rabies and its unfinished impact on modern life yet might be the reason for their conception about the rabies.

Table 3. Percentage of the respondents of different category regarding the type and place for treatment of rabies taken from

\begin{tabular}{|c|c|c|c|c|}
\hline \multirow{2}{*}{ Category } & \multirow{2}{*}{ Treatment taken from } & \multicolumn{2}{|c|}{ Division } & \multirow{2}{*}{$\begin{array}{c}\text { Total } \\
\% \text { (Number) }\end{array}$} \\
\hline & & $\begin{array}{c}\text { Rangpur } \\
\% \text { (Number) }\end{array}$ & $\begin{array}{l}\text { Chittagong } \\
\% \text { (Number) }\end{array}$ & \\
\hline \multirow{2}{*}{ Common People } & Traditional healer & $7.1(8)$ & $5.3(7)$ & $6.0(15)$ \\
\hline & Hospital doctor & $92.9(105)$ & 94.7 (126) & $94.0(231)$ \\
\hline School Teacher & Hospital doctor & $100.0(59)$ & $100.0(59)$ & $100.0(118)$ \\
\hline Peoples' Representative & Hospital doctor & $100.0(9)$ & $100.0(6)$ & $100.0(15)$ \\
\hline Political Leader & Hospital doctor & $100.0(18)$ & $100.0(15)$ & $100.0(33)$ \\
\hline Doctor & Hospital doctor & $100.0(30)$ & $100.0(30)$ & $100.0(60)$ \\
\hline Nurse + MT & Hospital doctor & $100.0(30)$ & $100.0(30)$ & $100.0(60)$ \\
\hline
\end{tabular}

The number of categories of the respondents who said that rabies can be prevented were: 112 common peoples, 59 school teachers, nine peoples' representatives, 18 political leaders, 30 doctors and 29 nurses + MTs in Rangpur division. Similarly, in Chittagong division, the numbers were 133, 59, $6,15,30$ and 30, respectively. Majority of the respondents of all categories in both divisions knew that rabies could be prevented by vaccine (Table 5).

Table 4. Percentage of the respondents of different category regarding the concept on fate of rabies

\begin{tabular}{lllll}
\hline \multirow{2}{*}{ Category } & Fate of rabies & \multicolumn{2}{c}{ Division } & \multirow{2}{*}{$\begin{array}{c}\text { Total } \\
\text { \% (Number) }\end{array}$} \\
\cline { 3 - 4 } & & $\begin{array}{c}\text { Rangpur } \\
\% \text { (Number) }\end{array}$ & $\begin{array}{c}\text { Chittagong } \\
\% \text { (Number) }\end{array}$ & (Numb \\
\hline Common People & Death & $91.9(102)$ & $93.8(121)$ & $92.9(223)$ \\
& Survive with disability & $1.8(2)$ & $0.8(1)$ & $1.25(3)$ \\
School Teacher & Survive as mad & $6.3(7)$ & $5.4(7)$ & $5.8(14)$ \\
& Death & $94.9(56)$ & $96.6(57)$ & $95.8(113)$ \\
Peoples' Representative & Survive with disability & $5.1(3)$ & $3.4(2)$ & $4.2(5)$ \\
Political Leader & Death & $100.0(9)$ & $100.0(6)$ & $100.0(15)$ \\
Doctor & Death & $100.0(18)$ & $100.0(14)$ & $100.0(32)$ \\
Nurse + MT & Death & $100.0(30)$ & $100.0(30)$ & $100.0(60)$ \\
\hline
\end{tabular}

In Rangpur division, 92 percent of the respondents thought that elimination would be the best procedure to control stray dog population, 3.7 percent thought other procedures, whereas, 4.3 percent were undecided. In Chittagong division, 91.3 percent of the respondents thought that elimination would be the 
best procedure to control stray dog population, four percents undecided, and only $4.7 \%$ respondents thought about other procedures for the stray dog control.

Table 5. Percentage of the respondents regarding the prevention of rabies

\begin{tabular}{llll}
\hline \multirow{2}{*}{ Category } & \multirow{2}{*}{ Prevention process of rabies } & \multicolumn{2}{c}{ Division } \\
\cline { 3 - 4 } & & \multicolumn{1}{c}{ Rangpur } & Chittagong \\
\hline Common People & By herbal drug & $6.2(7)$ & $5.3(7)$ \\
& By vaccine & $90.2(101)$ & $91.0(121)$ \\
& By other drug & $3.6(4)$ & $3.8(5)$ \\
School Teacher & By vaccine & $100.0(59)$ & $100.0(59)$ \\
People Representative & By vaccine & $100.0(9)$ & $100.0(6)$ \\
Political Leader & By vaccine & $100.0(18)$ & $100.0(15)$ \\
Doctor & By vaccine & $100.0(30)$ & $100.0(30)$ \\
Nurse + MT & By vaccine & $100.0(29)$ & $100.0(30)$ \\
\hline
\end{tabular}

In Rangpur division, 88 percent of the respondents thought that local Government agency should control stray dogs and 4.7 percent thought that people in the community should be responsible for controlling the stray dogs. Similarly, in Chittagong division, 88.3 percent of the respondents thought that local Government agency should be responsible in controlling stray dogs and 4.7 percent thought that people in the community should control the stay dogs (Table 6).

Table 6. Percentage of the respondents commenting on the agency/institution responsible for controlling stray dogs

\begin{tabular}{llll}
\hline \multirow{2}{*}{ Institution responsible } & \multicolumn{2}{c}{ Division } & $\begin{array}{l}\text { Total } \\
\% \text { (Number) }\end{array}$ \\
\cline { 2 - 3 } & $\begin{array}{l}\text { Rangpur } \\
\% \text { (Number) }\end{array}$ & $\begin{array}{l}\text { Chittagong } \\
\% \text { (Number) }\end{array}$ & \\
\hline People in the community & $4.7(14)$ & $4.7(14)$ & $4.7(28)$ \\
NGOs & $7.3(22)$ & $7.0(21)$ & $7.1(43)$ \\
Local Government agency & $88.0(264)$ & $88.3(265)$ & $88.2(529)$ \\
Total & $100.0(300)$ & $100.0(300)$ & $100.0(600)$ \\
\hline
\end{tabular}

In Rangpur division 87.3 percents of the respondents thought that elimination would be the best procedure to control poorly supervised dogs and three percents thought that animal birth control would be the best way to control poorly supervised dogs. In Chittagong division 88 percents of the respondents thought that elimination would be the best way to control poorly supervised dogs and 2.3 percents thought that animal birth control would be the best way to control poorly supervised dogs. In both Rangpur and Chittagong division, $9.7 \%$ of the respondents were undecided to control poorly supervised dogs. 
Bangladesh is a rabies endemic area although there is no accurate statistical data on rabies collected in this country. Till now, there is no rabies control Program or Project under Ministry of Health \& Family Welfare or no coordinated effort, but few arrangements like post-exposure vaccination to dog bite victims by locally produced nerve tissue vaccine and elimination of stray dogs occasionally done by the Dhaka City Corporation and Pourashava (Local government organizations). Pet dog registration and vaccination is very limited. Nerve tissue vaccine is neurotoxin and its production are also scanty and not available in Health care centers adequately. Some people use tissue culture vaccine with high price from the market (BARA 2010). In the present study, almost all the participants believed that rabies could be prevented by vaccination programme. This kind of perception was high among educated and high income groups of people. The availability of the vaccine is also a factor for this development. In Sri Lanka, there is a high level of awareness regarding the prevention of rabies by vaccination. This might be due to the availability of information from multiple sources including government campaigns and mass media in addition to free medical services in government hospitals (Agarwal and Reddaiah 2003).

In Bangladesh, the Institute of Public Health is the only government institute manufacturing and supplying 7,00,000 doses of simple type anti rabies vaccine. Besides this, Bangladesh imports tissue culture anti rabies vaccines for both human and veterinary use. Approximately five million $\mathrm{ml}$ of nervous tissue vaccine is produced annually for post-exposure prophylaxis of human beings and animals (WHO 2004).

The Veterinary Public Health (VPH) section of the Department of Livestock (DLS), since its establishment in 1985, has initiated a country-wide rabies control program. Under this program each Thana and municipal authority are requested to implement the program with a minimum budget under the supervision of the veterinary officials of DLS. The program includes the elimination of stray dogs, registration and vaccination of pet dogs and logistic support in the form of technical support and publicity campaigns. Although a canine rabies control program has been initiated by the VPH section since 1985, its success was very limited due to the shortage of manpower, diagnostic facilities, coordination among different organizations and financial support for conducting the control program (Report of the symposium on Rabies control in Asian Countries).

About 100,000 patients receive Post Exposure Treatment (PET) annually in Bangladesh. Most patients in this country take Nerve Tissue Vaccines (NTV) as part of the PET, but the use of Tissue Culture Vaccine (TCV) has been increased 
lately. Use of Rabies Immune Globulin (RIG) is very limited because of its high price and inadequate supply. About 150 cases of human rabies are admitted to the Infectious Disease Hospital, Dhaka (IDH) every year (BARA 2010).

Rabies is a fatal but easily preventable disease (WHO 2005). Despite trials with various antiviral agents, there is no therapy of proven value once the disease is developed (Jackson et al. 2003). Appropriate care of wound, adequate PET with modern TCV with RIG (when indicated) according to WHO guideline can prevent the disease amongst most of the persons exposed to rabid animal (WHO 1992).

\section{LITERATURE CITED}

AGARWAL, N. and REDDAIAH, V. P. 2003. Knowledge, attitude and practice following dog bite: a community-based epidemiological study. Perspectives and Issues, 26:154-161

BARA. 2010. Bangladesh Anti Rabies Alliance. Issue 1. Dhaka.

BERAN, G. W. and STEELE, J. H. 1994. Rabies and infections by rabies related virus. In: Beran, G.W. Handbook of Zoonoses, Section B, 2nd edition. CRC Press, Inc. Boca Raton, Ann Arbor. 307- $357 \mathrm{pp}$

CDC. 2011. Centers for Disease Control and Prevention. http://www.cdc.gov/rabies

JACKSON, A.C., WARRELL, M.J., RAPPRECHT, C.E., ERTL, H.C.J., DIETZSCHOLD, B. and O’REILLY, M. 2003. Management of rabies in humans. Clin. Infect. Dis. 36: 60-3.

KNOBEL, D.L., CLEAVELAND, S. and COLMAN, P.G. 2005. Re-evaluating the burden of rabies in Africa and Asia. Bull. Wld. Hlth. Org. 83: 360.

KREBS, J.W., MANDEL, E.J., SWERDLOW, D.L. and RUPPRECHT, C.E. 2004. Rabies surveillance in the United States during 2003. J. Am. Vet. Med. Assoc. 225: 1837-1849.

MATIBAG, G.C., KAMIGAKI, T., KUMARASIRI, P.V.R., WIJEWARDANA, T.G., KALUPAHANA, A.W., DISSANAYAKE, D.R.A., De SILVA, D.D.N., De S. GUNAWARDENA, G.S.P., OBAYASHI, Y., KANDA, K. and TAMASHIRO, H. (2007). Knowledge, Attitudes, and Practices Survey of Rabies in a Community in Sri Lanka. Environ. Hlth. Prevent. Med 12: 84-89.

MATTER, H.C., WANDELER, A.I., NEUENSCHWANDER, B.E., HARISCHANDRA, P.A.L. and MESLIN, F.X. 2000. Study of the dog population and rabies control activities in the Mirigama area of Sri Lanka. Acta Tropica 75: 95-108.

MESSENGER, S.L., SMITH, J.S. and RUPPRECHT, C.E. 2002. Emerging epidemiology of batassociated cryptic cases of rabies in humans in United States. Clin. Infec.t Dis. 35: 738.

Rabies Response Project Bangladesh An initial Inquiryhttp://www.brown.edu/Courses/Bio_160/ Projects 1999/rabies/epid.html

Report of the symposium on Rabies control in Asian Countries. WHO/Rab.Res./93.94

Report. (2004). The work of WHO in South-East Asia Region (WHO/SEARO, New Delhi)

REYNES, J.M., MOLIA, S., AUDRY, L., HOUT, S., NGIN, S. and WALSTON, J. 2004. Serologic evidence of Lyssavirus infection in bats, Cambodia. Emerg. Infect. Dis. 10(12): 2231-2234.

SEHGAL, S., BHATTACHANYA, D. and BHARDWAJ, M. 1997. Longitudinal studies of the safety and efficacy of human antirabies vaccine in an endemic country- India [abstract no 6.06]. In: Proceedings of the International Rabies Meeting (Paris). Paris: Institut Pasteur. 
SINGH, J., JAIN, D.C., BHATIA, R., ICHHPUJANI, R.L., HARIT, A.K. and PANDA, R.C. 2001. Epidemiological characteristics of rabies in Delhi and surrounding areas, 1998. Indian Pediatrics 38: 1354-1360.

WHO. 1992. Expert Committee on Rabies. World Health Organ Tech. Rep. Ser, no. 824.

WHO. 2004. Expert Consultation on Report rabies: first report. 2004. Geneva, World Health Organization.

WHO. 2005. Expert Consultation Report on rabies. WHO Tech. Rep. Ser. Abstract 931, p. 88.

Wilde, H. 1997. Rabies 1996. Internat. J. Infect. Dis. 1: 135-142

(Manuscript received on November 1, 2011; revised on January 21, 2012) 